\title{
Typology of beef production systems according to bioeconomic efficiency in the south of Brazil
}

\section{Maria Eugênia Andrighetto Canozzi ${ }^{1}$ (D) Pedro Rocha Marques ${ }^{2}$ Odilene de Souza Teixeira $^{2}$ (D) Concepta Margaret McManus Pimentel ${ }^{3}$ (D) Matheus Dhein Dill ${ }^{4,5}$ (D) Júlio Otávio Jardim Barcellos ${ }^{2^{*}}$ (D)}

${ }^{1}$ Programa Producción de Carne y Lana, Instituto Nacional de Investigación Agropecuaria (INIA), Colonia, Uruguay.

${ }^{2}$ Departamento de Zootecnia, Universidade Federal do Rio Grande do Sul (UFRGS), 91540-000, Porto Alegre, RS, Brasil. E-mail: julio.barcellos@ufrgs.br. "Corresponding author.

${ }^{3}$ Instituto de Ciências Biológicas, Universidade Federal de Brasília (UnB), Brasília, DF, Brasil.

${ }^{4}$ Unidade Acadêmica de Garanhuns (UAG), Universidade Federal Rural de Pernambuco (UFRPE), Garanhuns, PE, Brasil.

${ }^{5}$ Departamento Interdisciplinar, Universidade Federal do Rio Grande do Sul (UFRGS), Tramandaí, RS, Brasil.

ABSTRACT: The objective of this study was to evaluate the bioeconomic efficiency of beef cattle production systems in the south of Brazil. A survey was conducted with 33 beef cattle farmers operating with complete cycle production systems in areas larger or equal to 900 ha. Answers were classified in two drivers, technology (TEC) and management (MAN), which were separated into subfactors with their respective components. Multiple correspondence analysis, Tukey test, cluster analysis, and Pearson correlation were the statistics procedures. The TEC components were above normal for Brazilian farmers, but the gross margin is still lower than that needed to generate financial resources for a proper remuneration of cattle farmer. Farmers were classified into three clusters according to bioeconomic efficiency: low (LEL), intermediate (IEL), or high-efficiency level (HEL). The TEC driver differentiated the LEL x HEL clusters and the MAN, mainly expressed in costs, the IEL x HEL. Positive correlation between age at first mating and age at slaughter in the HEL cluster explains the higher costs when compared to IEL because of the use of differentiated feed resources. Investments in technologies related to herd feeding in HEL cluster improved the productivity by only $20 \%$ and the cost per hectare by 95 USD ha ${ }^{-1}$ in comparison to IEL cluster. The main differences between farmers are because of the use of technologies related to feeding and cost management. Therefore, before implementing a new technology, an economic evaluation is necessary.

Key words: animal production, cattle, cluster analysis, production cost.

Tipologia de sistemas de produção de carne bovina de acordo com a eficiência bioeconômica no sul do Brasil

RESUMO: O objetivo deste estudo foi avaliar a eficiência bioeconômica em sistemas de produção de bovinos de corte no sul do Brasil. A pesquisa foi realizada com 33 pecuaristas que operam com sistemas de produção baseado em ciclo completo, em áreas maiores ou iguais a 900 hectares. As respostas foram classificadas em dois fatores: tecnologia (TEC) e gestão (GES), os quais foram separados em subfatores com seus respectivos componentes. A análise de correspondência múltipla, teste de Tukey, análise de cluster e correlação de Pearson foram os procedimentos estatísticos. Os componentes do TEC estavam acima do normal para os pecuaristas brasileiros, mas a margem bruta ainda é menor do que a necessária para gerar recursos financeiros para uma remuneração adequada ao pecuarista. Os pecuaristas foram classificados em três grupos de acordo com a eficiência bioeconômica: baixo (BNE), intermediário (INE) ou alto nível de eficiência (ANE). O driver TEC diferenciou os clusters BNE x ANE e o GES, expresso principalmente em custos, o INE x ANE. A correlação positiva entre a idade no primeiro acasalamento e a idade ao abate no agrupamento ANE explica os custos mais elevados quando comparados aos INE, devido ao uso de recursos alimentares diferenciados. Os investimentos em tecnologias relacionadas à alimentação de rebanho no agrupamento ANE

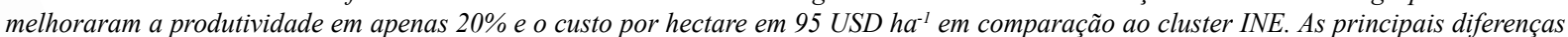
entre os pecuaristas se devem ao uso de tecnologias relacionadas à alimentação e ao gerenciamento de custos. Portanto, antes de implementar uma nova tecnologia, uma avaliação econômica é necessária.

Palavras-chave: produção animal, bovinos, análise de cluster, custo de produção.

\section{INTRODUCTION}

Advances in animal production over the past decade, especially in the Mercosur countries, are challenging beef farmers to increase efficiency in the use of biological and economic resources to achieve satisfactory results and to maintain their activity (BARCELLOS et al., 2015). Productive and economic indicators of Brazilian livestock are inferior when compared to their main competitors, 
Australia and the USA (USDA, 2016). This lower productivity is mainly because of the low productive efficiency, low pregnancy, and growth rates, results which influence the sector's competitiveness (OAIGEN et al., 2013).

These indicators are observed in the different regions of the country, including southern Brazil, showing the need to increase the bioeconomic efficiency of the activity (MARQUES et al., 2017). MCMANUS et al. (2016) showed that the growth of cattle production in the southern region of Brazil has decreased, as well as a reduction in herd size or internal migration over the period studied (19772011), and so efficiency of production is necessary to maintain the importance of this farm activity within the region.

Analysis of the bioeconomic efficiency allows the evaluation of how biological resources, as soil, pastures, animals, and economic resources are being used on farms. Thus, different combinations of land use, product price, production cost, productivity, and capital invested in animals determine the efficiency of the system (LAMPERT et al., 2012). Despite their importance, methods that use the typology of cattle farmers to evaluate their efficiency profile in the production system are still scarce (LAOUBI \& YAMAO, 2009; MCDERMOTT et al., 2010; MARQUES et al., 2011; GABBI et al., 2013). These methods are necessary, since within the same region there are differences in the productive efficiency of cattle farmers and these needs to be measured and classified. Thus, we investigated the typology of farmers to evaluate the bioeconomic efficiency of beef production systems in Rio Grande do Sul State, Brazil.

\section{MATERIALS AND METHODS}

The research was conducted with beef cattle farmers from the western frontier region of the state of Rio Grande do Sul, Brazil (Figure 1), including eight municipalities that had the largest cattle herds (Alegrete, Santana do Livramento, São Gabriel, Rosário do Sul, Uruguaiana, Quaraí, Itaqui and São Borja), representing $90 \%$ of the regional beef cattle production.

We interviewed 33 beef cattle farmers, which represents $7 \%$ of the total farms, selected by

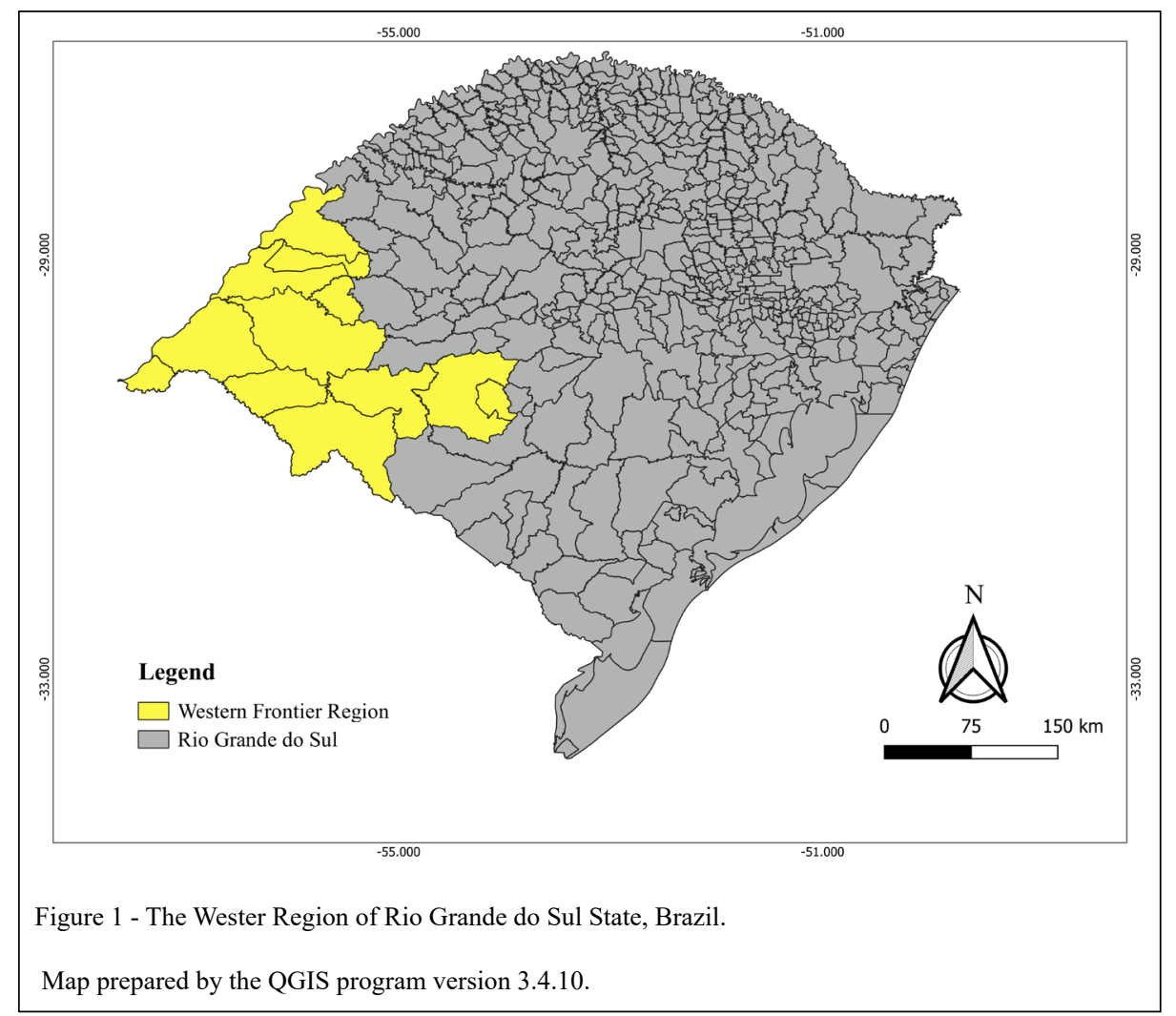

Ciência Rural, v.49, n.10, 2019. 
a team of researchers, as they maintained complete cycle production systems on their farms. Six types of livestock production systems were identified: i) cattle + sheep; ii) cattle + sheep + horses; iii) crops + cattle + sheep + horses; iv) crops + cattle + horses; v) crops + cattle; vi) crops + cattle + sheep, stands out the importance of systems with agriculture in this region. The main breeds used were the British (Angus and Hereford) and the synthetic breeds (Braford and Brangus). The minimum area of farms was 900 ha (Table 1). The productive and economic records were from the base year of 2012 .

As this research included complex livestock production systems, the definition of productive and economic indicators was conducted by a multidisciplinary team of researchers, consultants, and university lecturers, as well as collecting data from scientific articles and extension services. Two drivers were determined, technology (TEC) and management (MAN); these were separated into subfactors with their respective components (Table 2 and 3 ).

The TEC and MAN drivers, and their respective subfactors, were identified and analyzed in terms of intensity of contribution to the efficiency of the production system (positive or negative) in a quantitative manner, since all components analyzed had a numerical indicator as a response. In the final sum, the subfactors of each driver totaled 1.00. To determine the weight of each subfactor, the technical team considered the degree of importance of that subfactor for the efficiency of the productive system. Parameters for the formation of clusters of farmers were determined after interviews were carried out since each production system presented a final score for each driver and subfactor.

For the responses of the cattle farmers interviewed, two results sheets were generated. In worksheet $A$, the numerical values of the components referring to each driver and subfactor were shown. In $B$, the simple harmonic mean of each interviewee in relation to the sample of respondents contained in worksheet $A$, called the "final score" (FS). The FS for each subfactor was used to evaluate how the interviewee scored in relation to the sample of cattle farmers assessed, obtained using the following equation:

$$
\text { FS: }\left[\left(\mathrm{S}_{\text {prod.system }}-\mathrm{S}_{\text {min }}\right) /\left(\mathrm{S}_{\max }-\mathrm{S}_{\min }\right)\right] * 100
$$

Where FS is the final score of the subfactor; $\mathrm{S}_{\text {prod.system }}$ is the score given by the interviewee to the subfactor; $\mathrm{S}_{\min }$ is the minimum score provided by the sample of farmers for the subfactor; $\mathrm{S}_{\max }$ is the maximum score given by the sample of farmers for the subfactor.

Statistical analyses were conducted using Statistical Analysis System software (SAS Inc, Cary, North Carolina). Multiple correspondence analyses were used to identify the relationships between farmers and components (drivers and subfactors) using the Ward method and square Euclidean distances as measures of similarity. Results presented by the clusters in worksheet $B$ were analyzed using the Tukey-Kramer test $(\mathrm{p}<0.001)$. Relationship of the subfactors and their components was obtained using Pearson correlation analysis, which was considered strong for positive and negative values above 0.7 .

\section{RESULTS}

Subfactor description of the productive system (PROD) (Table 4) presented mean values for stocking rate, age at first mating, and slaughtering of 0.90 AU ha-1 (Animal Unit $=450 \mathrm{~kg} \mathrm{BW}$ ), 24 months and 30 months, respectively. The mean values for the reproductive indexes were $74 \%$ for the pregnancy rate and $69 \%$ for the calving rate. In health management, the mortality rate was above $2 \%$. Animal production indicators, such as productivity per area, off take, and weaning rates had mean values of $123 \mathrm{~kg} \mathrm{ha}^{-1}$ per year, $26.8 \%$, and $68.8 \%$, respectively. Analysis of the MAN driver, through the evaluation of the economic

Table 1 - Description of the area, cattle herd, sheep herd and crop area of the farmers.

\begin{tabular}{lccc}
\hline Description & Unit & Mean & SD \\
\hline Total area of farms & ha & 4189.78 & \pm 3429.38 \\
Cattle herd & Head & 2978.16 & \pm 2321.91 \\
Sheep flock & Head & 781.80 & \pm 1250.77 \\
Area of crops & ha & 940.58 & \pm 1520.89 \\
\hline
\end{tabular}

$\mathrm{SD}=$ standard deviation 
Table 2 - Technology (TEC) driver with its subfactors and their components.

\begin{tabular}{|c|c|}
\hline Subfactor and Variable(s) & Unit/weight \\
\hline $\begin{array}{l}\text { Description of the production system } \\
\text { (PROD) }\end{array}$ & 0.13 \\
\hline Overall stocking rate & $\mathrm{AU}_{\mathrm{ha}}{ }^{-1}$ \\
\hline Age at first mating & months \\
\hline Slaughter age & months \\
\hline $\begin{array}{l}\text { Quality, management and pasture species } \\
\text { (PAST) }\end{array}$ & 0.19 \\
\hline Pasture stocking rate & $\mathrm{AU}_{\mathrm{ha}}{ }^{-1}$ \\
\hline $\begin{array}{l}\text { Number of soil chemical analyses per year } \\
\text { (CTC, } \mathrm{Ph}, \mathrm{P}, \mathrm{K} \text { and } \mathrm{Al} \text { ) }\end{array}$ & $\mathrm{n}$ analysis \\
\hline Applications of NPK per year & $\mathrm{kg} \mathrm{ha}^{-1}$ per year \\
\hline Types of pasture & 1 \\
\hline ADG at pasture & $\mathrm{kg}_{\text {day }}{ }^{-1}$ \\
\hline Animal supplementation (SUP) & 0.19 \\
\hline ADG with supplementation & $\mathrm{kg}$ day $^{-1}$ \\
\hline Length of trough per animal & Cm per animal \\
\hline TDN of the supplement & $\%$ \\
\hline $\mathrm{CP}$ of the supplement & $\%$ \\
\hline $\begin{array}{l}\text { Productivity per area of the area } \\
\text { supplemented }\end{array}$ & $\mathrm{kg} \mathrm{ha}^{-1}$ per year \\
\hline Reproductive management (REP) & 0.13 \\
\hline Pregnancy rate & $\%$ \\
\hline Calving rate & $\%$ \\
\hline Abortion rate & $\%$ \\
\hline Cows: bull ratio & $\mathrm{n}^{\circ}$ cows per bull \\
\hline Weight of heifer $30 \mathrm{~d}$ before mating & $\mathrm{kg}$ \\
\hline Genetics (GEN) & 0.06 \\
\hline Breeds used & 2 \\
\hline Weaning weight & $\mathrm{kg}$ \\
\hline Health management (HEA) & 0.19 \\
\hline Number of active principles used per year & $\mathrm{n}$ active principles \\
\hline Overall mortality rate & $\%$ \\
\hline Baths or tick treatments per year & $\mathrm{n}$ treatments \\
\hline Interval between baths treatments & days \\
\hline Mortality rate up to one year of age & $\%$ \\
\hline Production control (PC) & 0.06 \\
\hline ADG for production system & $\mathrm{kg} \mathrm{day}^{-1}$ \\
\hline Productivity per area of production system & $\mathrm{kg} \mathrm{ha}^{-1}$ \\
\hline Offtake rate & $\%$ \\
\hline Weaning rate & $\%$ \\
\hline Routine animal management (ROUT) & 0.06 \\
\hline Number of weighing per year & n weightings \\
\hline Carrying capacity evaluation per year & $\mathrm{n}$ evaluations \\
\hline Number of dosing for endoparasites per year & $\mathrm{n}$ dosings \\
\hline
\end{tabular}

AU: animal unit $=450 \mathrm{~kg} \mathrm{BW}$; ADG: average daily weight gain; TDN: total digestible nutrients; CP: crude protein; $n$ : number of samples; U: units; ${ }^{1}$ unit referred as pasture type (summer, winter, or winter/summer); ${ }^{2}$ qualitative unit of breed type. indicators, showed an average cost of USD 141.20 $\mathrm{ha}^{-1}$, representing USD 1.39/kg LW produced and gross margin for ha was USD 52.21 .

In the cluster analysis, the formation of three groups was identified: low (LEL), intermediate (IEL), and high (HEL) level of efficiency (Table 5). The TEC driver with the components' age at first mating, soil chemical analyses, pregnancy rate, productivity per area, weaning rate, number of weighing, and supplementation were responsible for statistically differentiating the LEL and HEL clusters. The IEL and HEL clusters differed in the components' age at first mating and slaughter, with consequences in the MAN driver components.

For farmers classified as HEL, a correlation was reported between age at first mating and age at slaughter $(0.790, \mathrm{p}=0.006)$; between productivity and offtake rate $(0.711, \mathrm{p}=0.03)$ and cost ha ${ }^{-1}(0.760$, $\mathrm{p}=0.001)$; and between soil chemical analyses and variation of the stock in the last five years $(0.666$, $\mathrm{p}=0.025$ ). In the IEL cluster, the correlation between age at first mating and slaughter was negative $(-0.708, p=0.001)$. In the same cluster, a correlation was observed between productivity and offtake rate (0.794, $\mathrm{p}<0.0001)$ and cost ha ${ }^{-1}(0.694, \mathrm{p}=0.001)$; between stocking of pastures and selling price of steers $(0.751, p=0.0003)$; and between the frequency of budget control and the evaluation of cash flow $(0.690, \mathrm{p}=0.001)$.

\section{DISCUSSION}

Productivity of the farms found through defining the typology of cattle farmers (BRAITO et al., 2011) characterized production systems with levels of efficiency above the normal for Brazilian cattle ranching (BARCELLOS et al., 2015), which justifies the high level of regional competitiveness (MARQUES et al., 2011). However, the gross margin is still lower than that needed to generate financial resources for a proper remuneration of the cattle farmer and to maintain/restore costs involved with the acquisition of fixed production resources, such as machinery, equipment, and facilities. Alternatively, the gross margin is adequate for the economy of the system, providing that the scale of the farm exceeds the minimum area for the region (ANUALPEC, 2015).

Variation among cattle farmers occurred basically in the aspect related to physical productivity, which shows that the investments made to increase the efficiency of the systems produced positive 
Table 3 - Management (MAN) driver with its subfactors and their components.

\begin{tabular}{|c|c|}
\hline Subfactor and variable(s) & Unit/weight \\
\hline Labor training (TRA) & 0.16 \\
\hline $\begin{array}{l}\text { Number of training sessions } \\
\text { per year }\end{array}$ & $\mathrm{n}$ sessions \\
\hline Patrimonial control (PAT) & 0.05 \\
\hline $\begin{array}{l}\text { Percentage of leased area over } \\
\text { total area }\end{array}$ & $\%$ \\
\hline $\begin{array}{l}\text { Variation of stock over last five } \\
\text { years }\end{array}$ & $\mathrm{Kg}$ \\
\hline $\begin{array}{l}\text { Quantity of tractors and } \\
\text { implements bought over the } \\
\text { last five years }\end{array}$ & $\mathrm{n}$ tractors and implements \\
\hline Budget control (BUD) & 0.11 \\
\hline $\begin{array}{l}\text { Frequency of cash flow } \\
\text { evaluation per year }\end{array}$ & $\mathrm{n}$ times \\
\hline $\begin{array}{l}\text { Frequency of budget } \\
\text { elaboration per year }\end{array}$ & $\mathrm{n}$ times \\
\hline Production cost control (PCC) & 0.16 \\
\hline Cost per area of farm per year & $\mathrm{USD} \mathrm{ha}^{-1}$ \\
\hline $\begin{array}{l}\text { Cost per kg of LW produced } \\
\text { per year }\end{array}$ & $\mathrm{USD} \mathrm{kg}^{-1}$ of LW produced \\
\hline $\begin{array}{l}\text { Calculation of financial } \\
\text { indicators (FI) }\end{array}$ & 0.11 \\
\hline $\begin{array}{l}\text { Gross margin per hectare per } \\
\text { year }\end{array}$ & USD ha $^{-1}$ \\
\hline $\begin{array}{l}\text { Acknowledgment of total cost } \\
\text { composition }\end{array}$ & 1 \\
\hline Herd identification (HI) & 0.11 \\
\hline Manner of use of ear tags & 2 \\
\hline $\begin{array}{l}\text { Number of animal counts per } \\
\text { year }\end{array}$ & n counts \\
\hline Marketing (MKT) & 0.11 \\
\hline $\begin{array}{l}\text { Mean price of cull cow sales } \\
\text { per year }\end{array}$ & $\mathrm{USD} \mathrm{kg}^{-1}$ \\
\hline $\begin{array}{l}\text { Mean price of steer sales per } \\
\text { year }\end{array}$ & $\mathrm{USD} \mathrm{kg}^{-1}$ \\
\hline $\begin{array}{l}\text { Mean price of calf sales per } \\
\text { year }\end{array}$ & $\mathrm{USD} \mathrm{kg}^{-1}$ \\
\hline $\begin{array}{l}\text { Informatization of the farm } \\
\text { (INF) }\end{array}$ & 0.05 \\
\hline Manner of using worksheets & 3 \\
\hline Scale of production (SP) & 0.16 \\
\hline Offtake rate & $\%$ \\
\hline Gross margin per area per year & USD year $^{-1}$ \\
\hline Number of staff on farm & n staff \\
\hline
\end{tabular}

LW: live weight; ${ }^{1}$ yes or no; ${ }^{2}$ unit referred as how ear tags are used (i.e., individual control, genetic control, management control); ${ }^{3}$ unit referred as how worksheets are used (i.e., cash flow, herd control).

responses (GOMES et al., 2015). Alternatively, when the analysis considered economic results, this difference practically disappears between the clusters, especially in the IEL $x$ HEL comparison. This may be associated, mainly, with cost management efficiency or the choice of higher risk or costly technologies to obtain the expected physical results (PEREIRA et al., 2016). Thus, the technology driver differentiated the LEL $x$ HEL clusters and the management, mainly expressed in costs, the IEL $x$ HEL. This shows that intensifying the systems requires greater management capacity, particularly for costs, and the technological efficiency is responsible for productive responses, since the adoption of certain practices does not always allow proportional appropriation of better economic results (NUTHALL, 2009; LAMPERT et al., 2012).

The LEL group, in relation to HEL, showed lower overall animal production indexes, especially for age at first mating and slaughter, and less efficient routine management; although, the cost was less per hectare. Generally, a lower cost in the production system is just one of the components that affect the result, since this is a combination of productivity and cost of production (HILL, 2014).

An intra-cluster analysis showed a positive correlation between age at first mating and age at slaughter in the HEL, explained by the simultaneous use of differentiated feed resources (cultivated pastures and/or supplementation) in two productive processes replacement heifers rearing and steers feeder/finishing (MARQUES et al., 2017). However, spending on these technologies also explains the higher costs in this group of producers when compared to IEL. In this cluster, the correlation between the two animal production parameters was negative, i.e. when mating at two years of age, the age of slaughter is delayed. This may be related to the feed deficit to improve both processes (STYGAR et al., 2014), since supplementation is performed only once per year; conversely, in the HEL cluster this practice is used, on average, three times a year. Moreover, producers classified as LEL use feeding improvement as a priority to sell the animals for slaughter up to 30 months, a similar parameter to those of IEL, and this age is considered appropriate for the region. However, these cattle farmers fail with respect to age at first mating of heifers (36 months), a variable that severely restricts productivity and economic outcome (BERETTA et al., 2001).

The HEL cluster presented an additional cost around $95 \mathrm{USD} \mathrm{ha}^{-1}$ in relation to IEL, and a productivity superiority of only $25 \mathrm{~kg}^{\mathrm{ha}}{ }^{-1}$. The difference between HEL and IEL is probably because of investments in technologies related to herd nutrition by producers classified as HEL, which increased the cost by $84 \%$ and productivity by only $20 \%$. These additional costs were not offset 
Table 4 - Mean values presented by beef cattle farmers interviewed for the components belonging to the TEC and MAN drivers.

\begin{tabular}{|c|c|c|c|c|}
\hline Component (unit) & Subfactor & $\mathrm{N}$ & Mean & SEM \\
\hline \multicolumn{5}{|c|}{----------------------------------------------------------------------------- } \\
\hline Age at first mating (months) & PROD & 31 & 24.12 & 7.20 \\
\hline Slaughter age (months) & PROD & 31 & 30.23 & 8.61 \\
\hline Overall stocking rate $\left(\mathrm{AU} \mathrm{ha}^{-1}\right)$ & PROD & 31 & 0.91 & 0.42 \\
\hline ADG at pasture $\left(\mathrm{kg} \mathrm{day}^{-1}\right)$ & PAST & 31 & 0.83 & 0.23 \\
\hline ADG with supplementation $\left(\mathrm{kg} \mathrm{day}^{-1}\right)$ & SUP & 29 & 1.050 & 0.298 \\
\hline Pregnancy rate $(\%)$ & REP & 31 & 74.23 & 9.41 \\
\hline Calving rate $(\%)$ & REP & 31 & 69.12 & 10.21 \\
\hline Abortion rate $(\%)$ & REP & 31 & 4.38 & 2.74 \\
\hline Cows: bull ratio ( $\mathrm{n}^{\circ}$ cows bull ${ }^{-1}$ ) & REP & 31 & 33.31 & 15.51 \\
\hline Weight of heifer $30 \mathrm{~d}$ before mating $(\mathrm{kg})$ & REP & 31 & 305.12 & 34.10 \\
\hline Weaning weight (kg) & GEN & 31 & 175.35 & 20.51 \\
\hline Mortality rate (\%) & HEA & 30 & 2.43 & 13.00 \\
\hline ADG for production system $\left(\mathrm{kg} \mathrm{day}^{-1}\right)$ & $\mathrm{PC}$ & 31 & 0.560 & 0.247 \\
\hline Productivity per area of production system $\left(\mathrm{kg} \mathrm{ha}^{-1}\right)$ & $\mathrm{PC}$ & 30 & 123.09 & 44.67 \\
\hline Offtake rate $(\%)$ & $\mathrm{PC} / \mathrm{SP}$ & 31 & 26.80 & 8.80 \\
\hline Weaning rate $(\%)$ & $\mathrm{PC}$ & 31 & 68.83 & 10.51 \\
\hline \multicolumn{5}{|c|}{ } \\
\hline Cost per area of farm per year (USD ha ${ }^{-1}$ ) & PCC & 31 & 141.20 & 83.39 \\
\hline Cost per kg of LW produced per year (USD kg ${ }^{-1}$ produced year ${ }^{-1}$ ) & PCC & 31 & 1.39 & 0.03 \\
\hline Mean price of cull cows sales per year (USD kg-1) & MKT & 31 & 1.51 & 0.08 \\
\hline Mean price of steers sales per year (USD kg-1) & MKT & 31 & 1.74 & 0.08 \\
\hline Mean price of calves sales per year (USD kg ${ }^{-1}$ ) & MKT & 20 & 2.08 & 0.27 \\
\hline Gross margin per area per year (USD ha $\left.{ }^{-1}\right)$ & FI / SP & 30 & 52.21 & 32.97 \\
\hline
\end{tabular}

ADG: average daily weight gain; PROD: description of the productive system; PAST: quality, management and pasture species; SUP: animal supplementation; REP: reproductive management; GEN: genetics; HEA: health management; PC: production control; PCC: production cost control; SP: scale of production; LW: live weight; MKT: marketing; FI: calculation of financial indicators. SEM: standard error of mean.

by increased productivity in the same proportion (STYGAR et al., 2014), reflecting a 16\% reduction in gross margin; although, this was not significant $(\mathrm{p}>$ $0.05)$. In addition, higher costs for ha were required to ensure greater productivity and offtake. In IEL, budget and cash flow control are performed less frequently, which did not prevent the cost $\mathrm{ha}^{-1}$ from being lower than in HEL. Therefore, from the point of view of bioeconomic efficiency, the IEL production systems were more efficient and with a gross margin per hectare higher.

These results confirmed that productivity gains are not always associated with economic gains in beef cattle(LAMPERT et al., 2012; ÁVILAetal., 2014). Furthermore, it is important to highlight that in the HEL cluster there is a special care in the monitoring of soil fertility, a variable that supports the intensification of forage resources with the maintenance of a stock of animals over a relatively long period. Thus, from the point of view of system management, the farmers of this cluster, regardless of the economic outcome, have a better overall view of the production system in the long term (TANURE et al., 2013).

The best economic result observed in the IEL cluster can be attributed to a set of managerial concerns identified by the positive correlation between productivity, offtake, and cost of production. Positive association between selling price and stocking of cultivated pastures also indicates the concern for technologies used in the fattening process (THUROW et al., 2009) and the possibility of selling animals for slaughter when the price is more favorable, usually between July and August in this region (NESPro, 2015). During this period, there is a shortage of animals for the industry, since the fattening of cattle, mainly occurs to grass fed; thus, the climatic effects of winter decrease the growth of natural forages and negatively influence in the 
Table 5 - Comparative analysis of the three different clusters for the components related to technology (TEC) and management (MAN) drivers.

\begin{tabular}{|c|c|c|c|c|c|}
\hline Component (unit) & LEL & IEL & HEL & SEM & $\mathrm{P}$ \\
\hline \multicolumn{6}{|c|}{ 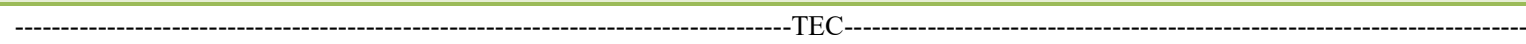 } \\
\hline Age at first mating (months) & $36 \mathrm{a}$ & $24 \mathrm{a}$ & $20 \mathrm{~b}$ & 3.1 & $<0.01$ \\
\hline Slaughter age (months) & $30 \mathrm{ab}$ & $33 a$ & $25 b$ & 2.7 & $<0.01$ \\
\hline Soil chemical analyses per year ( $\mathrm{n}$ analysis) & $0 \mathrm{a}$ & $1 \mathrm{a}$ & $1.9 \mathrm{~b}$ & 0.03 & $<0.01$ \\
\hline Pregnancy rate $(\%)$ & $64 a$ & $73 \mathrm{ab}$ & $79 b$ & 6.2 & $<0.01$ \\
\hline Productivity per area $\left(\mathrm{kg} \mathrm{ha}^{-1}\right)$ & $60 \mathrm{a}$ & $12 \mathrm{ab}$ & $145 b$ & 10.2 & $<0.01$ \\
\hline Weaning rate $(\%)$ & $56 \mathrm{a}$ & $67.5 \mathrm{ab}$ & $74 b$ & 4.9 & $<0.01$ \\
\hline Number of weighing per year ( $\mathrm{n}$ times) & $4 a$ & $3 a$ & $8 \mathrm{~b}$ & 0.43 & $<0.01$ \\
\hline Suplementation ( $\mathrm{n}$ times year ${ }^{-1}$ ) & 1a & $1 \mathrm{ab}$ & $3 b$ & 0.5 & $<0.01$ \\
\hline \multicolumn{6}{|c|}{ 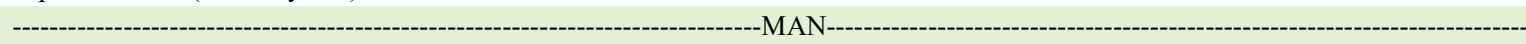 } \\
\hline Cost per area (USD ha-1) & $98.74 a$ & $113.57 \mathrm{a}$ & $208.22 b$ & 16.0 & $<0.01$ \\
\hline Budget control ( $\mathrm{n}$ times year ${ }^{-1}$ ) & 1a & $1 \mathrm{a}$ & $3 b$ & 0.7 & $<0.01$ \\
\hline Cash flow (n times year ${ }^{-1}$ ) & $2 \mathrm{a}$ & 1a & $3 b$ & 0.89 & $<0.01$ \\
\hline Manner of using of worksheets & $2 \mathrm{ab}$ & 1a & $3 b$ & 0.9 & $<0.01$ \\
\hline Number of animal counts per year ( $\mathrm{n}$ counts) & $3 \mathrm{ab}$ & $2 b$ & $3 a$ & 0.15 & $<0.01$ \\
\hline Manner of use of ear tags & $1 \mathrm{ab}$ & 1a & $2 b$ & 0.43 & $<0.01$ \\
\hline Gross margin (USD ha-1) & 31.72 & 57.81 & 48.40 & 3.2 & NS \\
\hline
\end{tabular}

LEL: low, IEL: intermediate and HEL: high efficiency levels; P value was calculated with Tukey test $(\mathrm{p}<0.01)$; SEM: standard error of mean.

amount of cattle for sale, causing an increase of the price of finished cattle (NESPro, 2016). However, the use of nutritional technologies in fattening can reduce the off-season, fetching the balance of price during the year (NESPro, 2018). Another factor that may have influenced the difference between clusters is the intensity of the technologies used, such as energy supplementation, which allows stabilizing the system (PÖTTER et al., 2008). In addition, it is important to note that there is a high prevalence of forage shortage in winter and summer because of drought (PAULINO et al., 2004).

The intention of cattle farmers to use practices that potentiate the use of natural pastures (BORGES et al., 2016), as well as the adjustment of the animal load according to the pasture availability (NABINGER et al., 2009) and the pasture types within the system, were the key variables in the dynamics of animal productivity. Alternatively, among the cattle farmers interviewed, there was a tendency to present a stocking rate superior to the carrying capacity of the pasture (CARVALHO et al., 2010), since there is a constant concern, in the three clusters, with the stability in the minimum herd size.

The year 2012 was favorable for animal production in the region, as the prices paid for steers were above the average in recent years (NESPro, 2015). In a complementary analysis, adjusting values for a 10-year period did not change the components that differentiated the clusters. This shows the lack of control that farmer has over the selling price of his animals and the importance of managing the variables under his control, especially the cost of production (HILL, 2014) and productivity. Therefore, the cattle farmer needs to improve his managerial capacity, since the vast majority of rural companies are unaware of their cost of production or do not measure their technical-financial indicators (OAIGEN \& BARCELLOS, 2008).

Although this research is concentrated in a specific region with expressive beef cattle production, it is understood that the evaluation of 33 famers is a limited number to measure the productive efficiency, mainly due the diversity of production systems. However, our proposal is innovative and with possibilities to expand to other regions and contribute to the decision-making of farmer managers to implement new technologies. Moreover, it is important to highlight that the limitation caused by the evaluation of only one year in this research, can be compensated by simulation studies repeating scenarios of other years. 


\section{CONCLUSION}

The evaluation of the level of bioeconomic efficiency of cattle farmers, through typology, showed that the main differences are because of the use of technologies related to feeding and cost management. The decision to increase productivity from an intermediate level does not always ensure better economic results. Then, before implementing a new technology, it is imperative to assess whether the benefit generated will be proportional to the increase in cost.

\section{ACKNOWLEDGEMENTS}

This study was supported by the Conselho Nacional de Desenvolvimento Científico e Tecnológico (CNPq), financial codes 150309/2014-7 and 166250/2015-5. And was financed in part by the Coordenação de Aperfeiçoamento de Pessoal de Nível Superior (CAPES), Brasil - Finance code 001.

\section{DECLARATION OF CONFLICT OF INTERESTS}

The authors declare no conflict of interest. The founding sponsors had no role in the design of the study; in the collection, analyses, or interpretation of data; in the writing of the manuscript, and in the decision to publish the results.

\section{AUTHORS' CONTRIBUTIONS}

The authors equally contributed to the manuscript.

\section{REFERENCES}

ANUAlPEC. Anuário da Pecuária Brasileira. São Paulo: Instituto FNP, 2015. 280p.

ÁVILA, M.R. et al. Distinct seasonal effects of nitrogen fertilization on herbage mass of subtropical grassland. Academia Journal of Agricultural Research, v.2, p.183-186, 2014. Available from: $<$ https://www.cabdirect.org/cabdirect/abstract/20153054216> Accessed: Sep. 24, 2016. doi: 10.15413/ajar.2012.0111.

BARCELLOS, J.O.J. et al. Aspectos estruturais e tecnológicos da cadeia produtiva da carne bovina no Brasil. In: Domínguez, R.N. et al. La ganadería en América Latina y el Caribe: alternativas para la producción competitiva, sustentable e incluyente de alimentos de origen animal. México: Editorial del Colegio de Postgraduados, 2015. p. 81-106.

BERETTA, V. et al. Productivity and biological efficiency of beef cowcalf systems differing in Age at first calving and herd calving rate in Rio Grande do Sul. Revista Brasileira de Zootecnia, v.4, p.1278-1286, 2001. Available from: $<$ http://www.scielo.br/scielo.php?pid=S1516$35982001000500022 \&$ script $=$ sci_abstract\&tlng $=$ pt $>$. Accessed: May, 13, 2013. doi: 10.1590/S1516-35982001000500022.

BRAITO, M. et al. Typology of agricultural land users in marginal rural areas. Journal of the Austrian Society of Agricultural
Economics, v.19, p.81-90, 2011. Available from: <https://oega. boku.ac.at/fileadmin/user_upload/Tagung/2009/Band_19_2/09 Braito_et_al_OEGA_JB_2009.pdf>. Accessed: Oct. 12, 2014.

BORGES, J.A.R. et al. Using the theory of planned behaviour to identify key beliefs underlying Brazilian cattle farmers' intention to use improved natural grassland: A MIMIC modelling approach. Land Use Policy, v.55, p.193-203, 2016. Available from: <https://www.sciencedirect.com/science/article/abs/pii/ S0264837716303155>. Accessed: Jan. 06, 2017. doi: 10.1016/j. landusepol.2016.04.004.

CARVALHO, P.C.F. et al. Managing grazing animals to achieve nutrient cycling and soil improvement in no-till integrated systems. Nutrient Cycling in Agroecosystems, v.88, p.259-273, 2010. Accessed: Feb. 17, 2014. Available from: <https://www.cabdirect.org/ cabdirect/abstract/20103367737>. doi: 10.1007/s10705-010-9360-x.

GABBI, A.M. et al. Typology and physical-chemical characterization of bovine milk produced with different productions strategies. Agricultural Systems, v.121, p.130-134, 2013. Accessed: Apr. 22, 2014. Available from: <https://www. sciencedirect.com/science/article/pii/S0308521X13000905>. doi: 10.1016/j.agsy.2013.07.004.

GOMES, E.G. et al. Economic and socio-environmental performance assessment of beef cattle production systems: a data envelopment analysis (DEA) approach with weight restrictions. Revista Brasileira de Zootecnia, v.44, p.219-225, 2015. Available from: <http://www.scielo.br/pdf/rbz/v44n6/1806-9290rbz-44-06-00219.pdf $>$. Accessed: Aug. 18, 2016. doi: 10.1590/ S1806-92902015000600004

HILL, B. An introduction to economics - Concepts for students of agriculture and the rural sector. Wallingford, UK: CABI. 2014, 256p.

LAMPERT, V.N. et al. Development and application of a bioeconomic efficiency index for beef cattle production in Rio Grande do Sul, Brazil. Revista Brasileira de Zootecnia, v.41, p.775-782, 2012. Available from: <http://www.scielo.br/pdf/rbz/ v41n3/42.pdf>. Accessed: Feb. 05, 2014. doi: 10.1590/S151635982012000300042 .

LAOUBI, K.; YAMAO, M. A typology of irrigated farms as a tool for sustainable agricultural development in irrigation schemes: The case of the East Mitidja scheme, Algeria. International Journal of Social Economics, v.36, p.813831, 2009. Available from: <https://www.emeraldinsight.com/doi/ abs/10.1108/03068290910967091>. Accessed: Sep. 22, 2014. doi: $10.1108 / 03068290910967091$.

MARQUES, P. R. et al. Competitiveness of beef farming in Rio Grande do Sul State, Brazil. Agricultural Systems, v.104, p.689693, 2011. Available from: <https:/www.sciencedirect.com/ science/article/pii/S0308521X11001168>. Accessed: Nov. 19, 2015. doi: 10.1016/j.agsy.2011.08.002.

MARQUES, P.R. et al. A proposal for the evaluation of the bioeconomic efficiency of beef cattle production systems. Revista Brasileira Zootecnia, v.46, p.65-71, 2017. Available from: $<$ http:// www.scielo.br/pdf/rbz/v46n1/1516-3598-rbz-46-01-00065.pdf >. Accessed: Feb. 14, 2018. doi: 10.1590/s1806-92902017000100010.

MCDERMOTT, J.J. et al. Sustaining intensification of smallholder livestock systems in the tropics. Livestock Science, v.130, p.95- 
109, 2010. Available from: <https:/www.sciencedirect.com/ science/article/abs/pii/S1871141310000776>. Accessed: May, 28, 2014. doi: 10.1016/j.livsci.2010.02.014.

MCMANUS, C. et al. Dynamics of cattle production in Brazil. PLOS ONE, v.11:e0147138, p. e0147138, 2016. Available from: $<$ https://journals.plos.org/plosone/article?id=10.1371/journal. pone.0147138>. Accessed: Mar. 13, 2016. doi: 10.1371/journal. pone. 0147138

NABINGER, C. et al. Produção animal com base no campo nativo: aplicações de resultados de pesquisa. In: Pillar, V.P. et al. Campos Sulinos: Conservação e uso sustentável da biodiversidade. Brasília, DF: Ministério do Meio Ambiente. 2009. p.175-198.

NESPro - Informativo NESPro \& Embrapa Pecuária Sul: Bovinocultura de Corte no Rio Grande do Sul. Porto Alegre, BR UFRGS, 2015. 2v. Available from: <http://www.ufrgs.br/nespro/ nespro_informativos/index.php>. Accessed: Jan. 25, 2018.

NESPro - Informativo NESPro \& Embrapa Pecuária Sul Bovinocultura de Corte do Rio Grande do Sul. Porto Alegre, BR: UFRGS, 2016. 3v. Available from: <http://www.ufrgs.br/nespro/ informativos/3/mobile/index.html $\# \mathrm{p}=1>$. Accessed: Jul. 03, 2019.

NESPro - Informativo NESPro \& Embrapa Pecuária Sul Bovinocultura de Corte do Rio Grande do Sul. Porto Alegre, BR: UFRGS, 2018. 4v. Available from: <http://www.ufrgs.br/nespro/ informativos/4/mobile/index.html\#p=2>. Accessed: Jul. 03, 2019.

NUTHALL, P. Modelling the origins of managerial ability in agricultural production. Australian Journal of Agricultural and Resource Economics, v.53, p.413-436, 2009. Available from: $<$ https:// onlinelibrary.wiley.com/doi/full/10.1111/j.1467-8489.2009.00459.x>. Accessed: Aug. 13, 2014. doi: 10.1111/j.1467-8489.2009.00459.x.

OAIGEN, R.P.; BARCELLOS, J.O.J. Gerenciamento e custo de produção. In: Moura, J.A. et al. Programa de atualização em medicina veterinária, Porto Alegre, BR: ARTMED. 2008, p.51-88.

OAIGEN, R.P. et al. Beef cattle production system competitiveness in the south of Brazil. Revista Archivos de Zootecnia, v.62, p.161-170, 2013. Available from: <http://scielo.isciii.es/pdf/azoo/ v62n238/art1.pdf>. Accessed: May, 18, 2015. doi: 10.4321/S000405922013000200001

PAULINO, M.F. et al. Suplementação de bovinos em pastagens: uma visão sistêmica. In: Simpósio de produção de gado de corte, Viçosa, MG: Universidade Federal de Viçosa. 2004, p. 93-144.

PEREIRA, M.A. et al. Assesing the diversity of values and goals amongst Brazilian commercial-scale progressive beef farmers using Q-methodology. Agricultural Systems, v.144, p.1-8, 2016. Available from: <https:/www.alice.cnptia.embrapa.br/bitstream/ doc/1061190/1/Assessingthediversityofvaluesandgoals.pdf $>$. Accessed: Jun. 27, 2018. doi: 10.1016/j.agsy.2016.01.004.

PÖTTER, L. et al. Suplementação de bovinos de corte: potencialidades na metade Sul - farelo de arroz. In: Jornada técnica em sistemas de produção de bovinos de corte e cadeia produtiva, Porto Alegre, BR: Universidade Federal do Rio Grande do Sul. 2008, p.80-86

STYGAR, A.H. et al. Optimal management of replacement heifers in a beef herd: A model for simultaneous optimization of rearing and breeding decisions. Journal Animal Science, v.92, p.3636-3649, 2014. Available from: <https://www.ncbi.nlm.nih.gov/pubmed/25074455> Accessed: Nov. 07, 2015. doi: 10.2527/jas.2010-7535.

TANURE, S. et al. Bioeconomic model of decision support system for farm management. Part I: Systemic conceptual modeling. Agricultural Systems, v.115, p.104-116, 2013. Available from: $<$ https://www.sciencedirect.com/science/article/pii/ S0308521X12001448>. Accessed: Jun. 16, 2015. doi: 10.1016/j. agsy.2012.08.008

THUROW, J.M. et al. Vegetation structure and ingestive behavior of steers in natural pasture in the state of Rio Grande do Sul. Revista Brasileira de Zootecnia, v.38, p.818-826, 2009. Available from: $<$ http://www.scielo.br/pdf/rbz/v38n5/06.pdf $>$. Accessed: Jun. 23, 2018. doi: 10.1590/S1516-35982009000500006.

USDA - Livestock and poultry: world markets and trade. Foreign Agriculture Service, Office of Global Analysis. 2016. Available from: $<$ https://apps.fas.usda.gov/psdonline/circulars/livestock_poultry.pdf $>$. Accessed: Dec. 27, 2017 